\title{
Identifikasi Kerusakan pada Gedung Gereja Suara Kebenaran Injil (GSKI Perdatam) di Perdatam, Jakarta Selatan James Rilatupa ${ }^{1}$ dan Sahala Simatupang ${ }^{2}$
}

1,2 Universitas Kristen Indoneisa, Jakarta, Indonesia

E-mail: james.rilatupa@uki.ac.id; sahala.simatupang@uki.ac.id;

\begin{abstract}
Abstrak
Potensi kerusakan suatu bangunan, baik bangunan lama atau pun yang relatif baru dibangun sangatlah besar. Umumnya kenampakan kerusakan yang terjadi terlihat setelah bangunan tersebut mulai dioperasikan. Pengabdian kepada masyarakat ini bertujuan untuk menduga nilai kondisi konstruksi bangunan Gedung GSKI Perdatam di Jl. Pengadegan Utara Raya No. 29, Pancoran, Jakarta Selatan. Selain itu, PKM ini juga berguna untuk mengetahui penyebab dari kerusakan komponen bangunan tersebut, sehingga dapat membantu manajemen Gedung GSKI Perdatam dalam aspek perawatan dan pemeliharaannya. Metode yang digunakana adalah dengan cara mengidentifikasi jenis kerusakan, baik dari segi arsitektur, manajemen konstruksi dan pemeliharaannya. Kerusakan pada gedung GSKI Perdatam terjadi pada komponen atap, plafon, dinding, lantai, utilitas, dan sanitasi. Bobot kerusakan berkisar antara $10-75$ persen pada masing-masing komponen yang rusak tersebut. Sebagian besar kerusakan yang terjadi disebabkan oleh rembesan air hujan. Kerusakan yang terkecil terdapat pada komponen lantai (10 persen) yang disebabkan oleh penggelembungan (popping); dan yang terbesar pada komponen dinding ( 75 persen).
\end{abstract}

Kata Kunci: identifikasi kerusakan; komponen bangunan.

\begin{abstract}
The potential for damage to a building, whether old or relatively new, is very large. Generally, the appearance of the damage that occurs is visible after the building starts operating. This community service aims to predict the value of the construction conditions of the GSKI Perdatam building on Jl. Pengadegan Utara Raya No. 29, Pancoran, South Jakarta. In addition, this PKM is also useful for knowing the cause of the damage to the building components, so that it can help the management of the GSKI Perdatam Building in its maintenance aspects. The method used is to identify the type of damage, both in terms of architecture, construction management and maintenance. Damage to the GSKI Perdatam building occurred in the roof, ceiling, walls, floors, utilities and sanitation components. Damage weight ranges from 10 - 75 percent for each of the damaged components. Most of the damage caused by rainwater seepage. The smallest damage was found in the floor components (10 percent) caused by popping; and the largest in the wall component (75 percent).
\end{abstract}

Keywords: damage identification; building components. 


\section{PENDAHULUAN}

Pada tahap perencanaan dan perancangan suatu bangunan, pertimbangan mengenai struktur bangunan memegang peranan yang penting (Randall, 2012). Walaupun banyak pembangunan gedung tidak/kurang memperhatikan masalah perawatan bangunan sejak tahap perencanaan dan perancangan, aspek perawatan pada saat operasional bangunan perlu menjadi bahan pertimbangan yang tidak kalah pentingnya (Rostiyanti, 2005). Perawatan gedung adalah usaha dan tindakan yang diperlukan dalam rangka mempertahankan kondisi gedung berikut sarananya agar tetap dalam kondisi sesuai spesifikasi teknis dan umur pakai perencanaan semula bangunan.

Perawatan gedung adalah suatu proses yang terus menerus untuk mengimbangi jasa dan biaya dalam suatu upaya memberikan rasa aman, nyaman dan memuaskan pengguna bangunan (Stanford, 2010). Seluruh asset berupa bangunan fisik, peralatan dan sumber daya manusia memerlukan perhatian dan perawatan yang bersamaan dengan penggunaannya (Schmid, 2014). Untuk itu di dalam bangunan perlu disediakan segala sesuatu yang dibutuhkan bagi metabolisme manusia, seperti udara dan air yang bersih, pengolah limbah, pengendalian suhu dan kelembaban udara, privasi, keamanan dan kenyamanan lainnya; baik yang berkaitan dengan aspek visual maupun pendengaran (Juwana, 2005).

Undang-Undang Republik Indonesia (UU RI) No. 28 Tahun 2002 tentang Bangunan Gedung, khususnya pada Pasal 37 ayat (3) beserta penjelasannya, dan Pasal 37 ayat (5) beserta Rancangan Peraturan Pemerintahnya, berisikan tentang pemeliharaan, perawatan dan pemeriksaan berkala pada bangunan. Sementara itu pada Pasal 18 ayat (1) dan Pasal 17 ayat (2) juga mencantumkan persyaratan kemampuan struktur bangunan gedung yang stabil dan kukuh dalam mendukung beban muatan termasuk yang timbul akibat perilaku alam (Umum, Undang-Undang Republik Indonesia No. 28/2002, 2002). Selain itu, pedoman tentang pengelolaan pemeliharaan dan perawatan gedung juga dijelaskan pada Peraturan Menteri Pekerjaan Umum nomor 45/PRT/M/2007 (Umum, 2007). Undangundang Pemerintah tersebut menjelaskan bahwa aspek pemeliharaan dan perawatan gedung perlu dilakukan, supaya pemanfaatan gedung dapat diperpanjang dengan melakukan perbaikan berkala karena tingkat lama pemakaian (usia pakai) setiap komponen gedung non struktural tidak sama.

Identifikasi terhadap kerusakan yang terjadi pada elemen bangunan perlu dilakukan dengan melihat bahwa begitu banyak kerusakan bangunan dengan penyebab yang berbeda (Nuswantoro, Juni 2010). Beberapa rumusan masalah yang mempengaruhi kenampakan kerusakan suatu bangunan dalam penelitian ini adalah sebagai berikut:

- Pengaruh iklim setempat berdampak langsung pada permukaan elemen dinding bagian luar gedung

- Dampak keberadaan vegetasi pada elemen dinding luar gedung

- Pengaruh mekanis pada bagian struktur dan elemen konstruksi ruang bagian dalam seperti plafon,dinding dan lantai

- Dampak pemilihan jenis material pada elemen konstruksi gedung

- Kondisi penurunan fungsi operasional utilitas bangunan gedung

- Pengendalian biaya perawatan yang proposional terkait dengan umur/masa pakai bangunan gedung

Umumnya sering ditemukan banyak gedung yang hanya melakukan perbaikan bila ditemukan kerusakan-kerusakan yang mengganggu dan umumnya tingkat kerusakan yang ditemukan sudah parah, sehingga memerlukan biaya perbaikan yang lebih besar daripada perawatan secara berkala dan terencana (J. Douglas and B. Ransom, 2013). Pekerjaan perawatan adalah sarana (manajemen bangunan) sehari-hari yang pada dasarnya dapat ditemui dalam bentuk :

a. Perawatan secara teratur atau terjadwal dengan baik untuk mencegah timbulnya kerusakan atau penurunan kondisi, sesuai dengan hasil pencatatan rutin proses penggunaan (perawatan sebelum atau menghindari adanya keluhan dari pengguna).

b. Usaha perawatan yang dilakukan bila telah nyata ada tanda-tanda kerusakan dini atau indikasi akan terjadi kerusakan, sehingga usaha perawatannya lebih banyak merupakan usaha koreksi atau pengembalian pada kondisi awalnya 
(perawatan sesudah atau hampir adanya keluhan).

Bangunan juga perlu dipertimbangkan atas aspek ekonomi, mudah dalam pelaksanaan konstruksinya dan tidak menyulitkan dalam pengoperasian dan perawatannya. Pelayanan gedung yang tidak diimbangi dengan kegiatan perawatan gedung akan mengakibatkan dampak kerugian yang cukup besar. Hal ini terjadi karena tidak ada pengetahuan lebih dini akan kerusakan suatu fasilitas, baik fisik ataupun utilitas (Wood, 2009). Pelayanan gedung yang tidak diimbangi dengan kegiatan perawatan gedung akan mengakibatkan dampak kerugian yang cukup besar. Hal ini terjadi karena tidak ada pengetahuan lebih dini akan kerusakan suatu fasilitas, baik fisik ataupun utilitas. Akibatnya kerusakan yang ditemui adalah kerusakan berat dan memerlukan biaya perbaikan yang mahal, bahkan tidak tertutup kemungkinan diperlukan penggantian pada fasilitas tersebut. Akibatnya kerusakan yang ditemui adalah kerusakan berat dan memerlukan biaya perbaikan yang mahal, bahkan tidak tertutup kemungkinan diperlukan penggantian pada fasilitas tersebut (Ratay, 2000).

Penurunan nilai bangunan terjadi karena usia dari komponen bangunan dan faktor perawatan (Wordsworth, 2001). Dalam proses pelaksanaan pemeriksaan suatu gedung, tentunya diperlukan ketersediaan informasi (data) yang nantinya akan membantu perencanaan dan pembiayaan dalam perawatan dan pemeliharaan gedung tersebut. Data yang diperoleh harus layak dan mencakup kondisi komponen bangunan yang ada dalam gedung yang diperiksa (Watt, 2007).

\section{METODE}

Bahan yang digunakan dalam investigasi ini adalah denah Bangunan dan gambar bangunan Gedung GSKI Perdatam, Jakarta Selatan; serta data visual dari gedung tersebut. Sementara itu, alat yang digunakan adalah alat perekam visual dan borang-borang pemeriksaan untuk data exciting.

Metode investigasi dilakukan dengan cara:

- melakukan pengamatan terhadap kondisi struktur gedung (upper struktur), lantai per lantai, baik pada area interior maupun eksterior

- menentukan lokasi kerusakan dengan cara mengidentifikasi jenis kerusakan, baik dari segi arsitektur, manajemen konstruksi dan pemeliharaan

- investigasi terhadap perbaikan yang sudah dilakukan terhadap komponen konstruksi yang telah diperbaiki.

\section{HASIL DAN PEMBAHASAN}

\section{Gedung GSKI Perdatam}

Gedung GSKI Perdatam terletak di Jl. Pengadegan Utara No. 27, Kelurahan Pengadegan, Kecamatan Pancoran, Jakarta Selatan. Gedung gereja ini awalnya berupa gubuk reot berukuran $10 \times 5 \mathrm{~m}^{2}$, dimana Pdt. Dr. Erastus Sabdono mengawali penggembalaannya pada tahun 1987. Saat itu, jemaatnya pun hanya berjumlah belasan orang. Seiring dengan berjalannya waktu dan pertumbuhan gereja, maka jemaat yang beribadah pun bertambah.

Pada tahun 1988, gereja tersebut mulai dibangun dengan dana yang terbatas. Namun demikian pada tahun 2009 terlihat gereja mulai miring, yang diduga akibat adanya penurunan pondasi gedung. Sejak saat itu, mulai dibentuk tim untuk merenovasi gedung gereja tersebut, dan pada tahun 2010 mulai dilakukan renovasi.

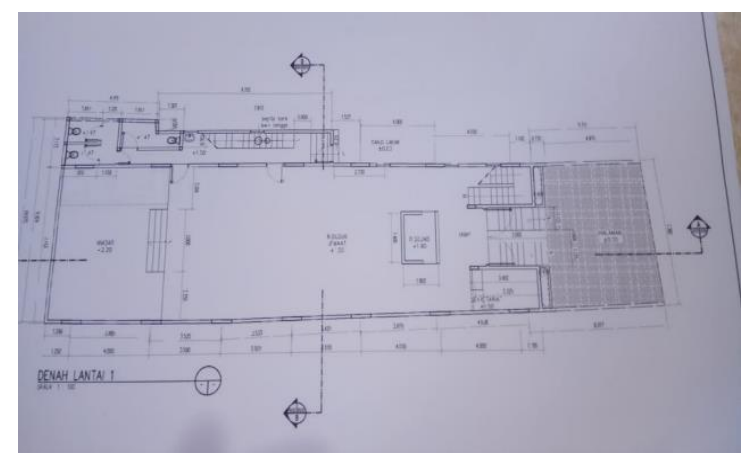

Gambar 1. Denah lantai 1

Pekerjaan renovasi yang dimulai sejak tahun 2010 berlangsung selama \pm 3 tahun, dan pada ahir tahun 2013 gedung GSKI Perdatam sudah mulai digunakan untuk tempat beribadah kembali. Gedung gereja yang direnovasi tersebut terdiri dari 2 lantai dan 
Volume 2, Nomor 2, Tahun 2020 Hal 458 - 464

1 lantai untuk balkon dan kantor, dimana lantai 1 digunakan untuk tempat ibadah umum (Gambar 1), lantai mezzanin untuk kantor sekretariat pelayanan (Gambar 2), dan lantai 2 untuk kegiatan sekolah minggu dan remaja serta dapur (area senvis) (Gambar 3).

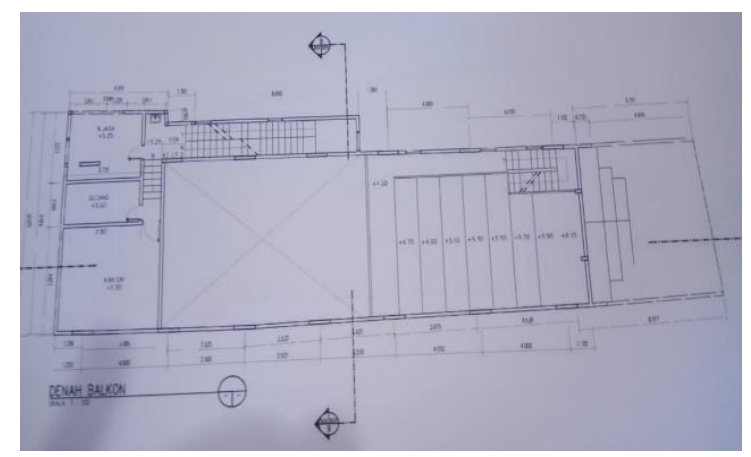

Gambar 2. Denah lantai mezzanin (balkon dan kantor).



Gambar 3. Denah lantai 2

\section{Kerusakan pada atap}

Kerusakan yang terjadi bagian atap gedung gereja ini adalah pada talang beton dan floor drain (Gambar 4 dan Gambar 5). Kerusakan pada bagian atap menyebabkan rembesan air pada plafon dan dinding bagian dalam dari gedung gereja ini. Bobot kerusakan pada bagian atap gereja mencapai 30 persen dari seluruh kerusakan yang terjadi pada atap gedung ini (Tabel 1). Kerusakan pada bagian atap menyebabkan rembesan air pada plafon dan dinding bagian dalam dari gedung gereja ini. Bobot kerusakan pada bagian atap gereja mencapai 30 persen dari seluruh kerusakan.



Gambar 4. Lubang saluran (floor drain) di dak beton



Gambar 5. Proses perbaikan pada bagian atap gedung GSKI Perdatam

Tabel 1. . Hasil pemeriksaan komponen Bangunan Gedung GSKI Perdatam

\begin{tabular}{cccc}
\hline No. & $\begin{array}{c}\text { Komponen } \\
\text { bangunan }\end{array}$ & $\begin{array}{c}\text { Sub komponen } \\
\text { bangunan }\end{array}$ & $\begin{array}{c}\text { Bobot terhadap } \\
\text { kerusakan (\%) }\end{array}$ \\
\hline 1. & Atap (25\%) & Talang beton dan floor & 30 \\
2. & Plain & 25 \\
3. & Dinding (10\%) & $\begin{array}{c}\text { Penutup plafon } \\
\text { Plester dinding dan }\end{array}$ & 75 \\
4. & Lantai (4\%) & Pengecatan waterproofing & Penutup lantai \\
5. & Utilitas (7\%) & Panel dan kabel listrik & 10 \\
6. & Sanitasi (4\%) & Wastafel & 25 \\
\hline
\end{tabular}




\section{Kerusakan pada plafon}

Plafon gedung gereja GSKI ini menggunakan material papan gipsum. Papan gipsum merupakan material yang terbuat dari campuran bahan kertas, yang berakibat tidak tahan air. Kerusakan yang terjadi pada plafon gedung gereja ini adalah adanya rembesan air hujan (Gambar 6). Bobot kerusakan pada plafon gereja mencapai 25 persen dari seluruh plafon gedung GSKI ini (Tabel 1).

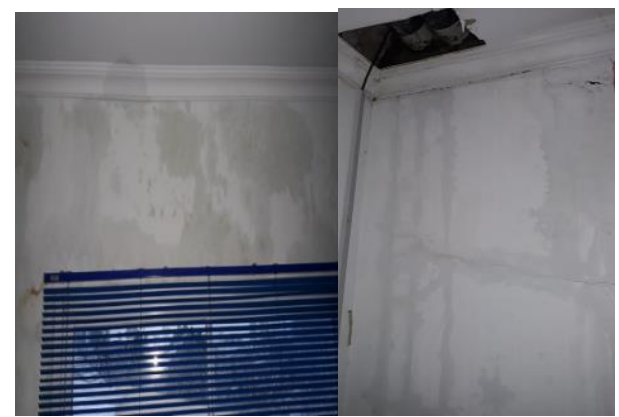

Gambar 6. Kerusakan pada plafon akibat rembesan air hujan

\section{Kerusakan pada dinding}

Kerusakan pada dinding ini disebabkan kerusakan pada atap dan talang betonnya. Rembesan air hujan pada dinding dalam tersebut mengkibatkan kerusakan pada cat dindingnya (Gambar 7).

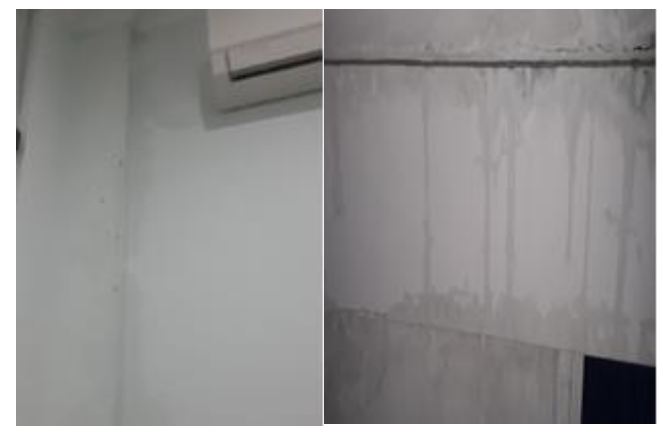

Gambar 7. Rembesan air hujan pada dinding dalam gedung GSKI Perdatam

Sementara itu, hujan juga menyebabkan cat dinding dan water proof pada dinding luar gedung gereja ini terkelupas (Gambar 8). Bobot kerusakan pada bagian atap gereja mencapai 75 persen dari seluruh kerusakan yang terjadi pada dinding gedung ini (Tabel 1). Kerusakan pada dinding merupkan kerusakan yang terbesar dari seluruh komponen bangunan gedung GSKI Perdatam.

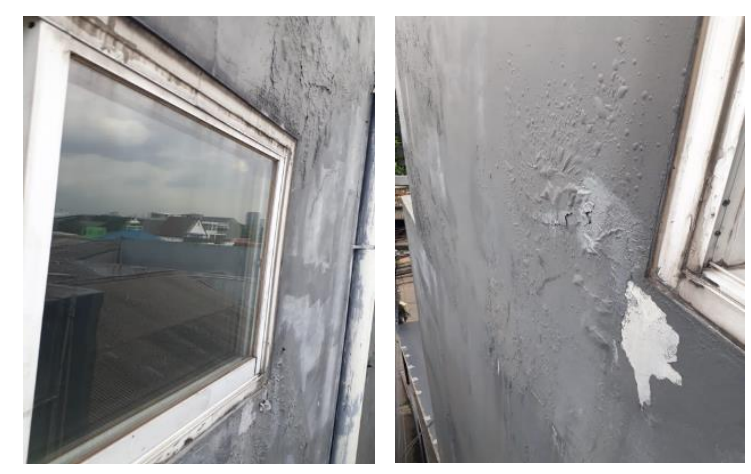

Gambar 8. Kerusakan pada dinding luar gedung GSKI Perdatam

\section{Kerusakan pada lantai}

Kerusakan yang terjadi bagian lantai gedung gereja adalah terjadinya penggelembungan (popping), sehingga lantai terangkat sendiri (Gambar 9). Kerusakan pada lantai ini dapat disebabkan oleh rembesan air yang masuk atau kurang padatnya adukan semen saat pemasangan lantai tersebut. Bobot kerusakan pada lantai gereja mencapai 10 persen dari seluruh kerusakan yang terjadi pada utilitas gedung ini (Tabel 1); dan merupakan kerusakan yang terkecil dari seluruh komponen gedung gereja ini.

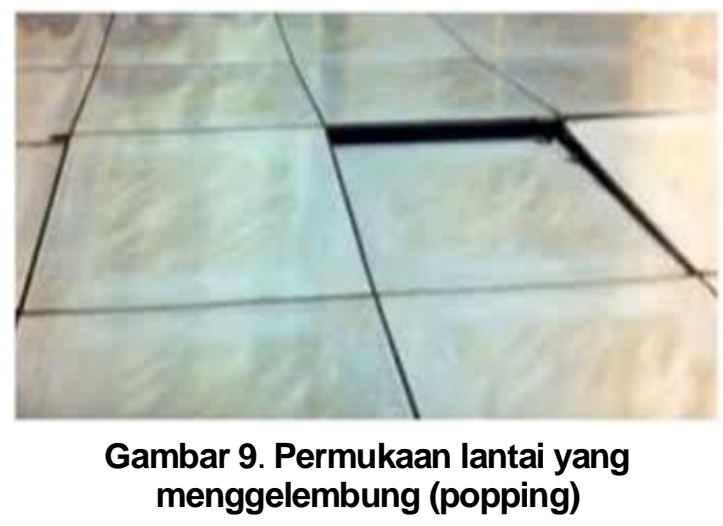

\section{Kerusakan pada utilitas gedung}

Kerusakan yang terjadi utilitas gedung gereja adalah adanya rembesan air hujan pada panel listrik (Gambar 10). Kerusakan pada panel listrik ini mengakibatkan gangguan pada fasilitas gedung, akibat terjadinya korslet. Untuk mengatasi hal tersebut, tentunya perbaikan pada atap perlu diperbaiki segera. Bobot kerusakan pada utilitas gereja mencapai 25 persen dari seluruh kerusakan yang terjadi pada utilitas gedung ini (Tabel 1). 



Gambar 10. Rembesan air hujan pada panel listrik.

\section{Kerusakan pada sanitasi gedung}

Kerusakan yang terjadi pada sanitasi gedung gereja adalah fungsi wastafel yang sudah mulai rusak, sehingga memerlukan perbaikan. Wastafel yang rusak terebut terletak di lantai 1 (Gambar 11). Kerusakan pada wastafel ini, dapat disebabkan oleh faktor manusia atau usia pemakaiannya.


Gambar 11. Perbaikan wastafel di lantai 1

Wastafel di lantai 1 ini memang sering digunakan oleh jemaat GSKI Perdatam, sehingga lebih mudah rusak dibandingkan dengan wastafel di lantai kantor dan lantai 2. Bobot kerusakan pada sanitasi gereja mencapai 20 persen dari seluruh kerusakan yang terjadi pada sanitasi gedung ini (Tabel 1).

\section{SIMPULAN}

Kerusakan yang ditemukan pada gedung gereja GSKI Perdatam umumnya karena kurangnya perawatan dan pemeliharaan yang dilakukan, terutama pada atap dan talang beton. Sejak renovasi pada tahun 2013 hingga 2020, memang belum dilakukan perawatan dan pemeliharaan pada gedung ini. Perawatan yang dilakukan hanya pada fasilitas yang digunakan untuk kegiatan ibadah.

Umumnya kerusakan terjadi pada komponen atap, plafon, dinding, lantai, utilitas dan sanitasi. Hampir semua kerusakan yang terjadi diakibatkan oleh rembesan air hujan. Persentase kerusakan bervariasi pada tiap-tiap komponen gedung dari 10 persen hingga 75 persn. Kerusakan terkecil (10 persen) ditemukan pada komponen lantai, dan kerusakan terbesar (75 persen) pada komponen dinding dalam dan dinding luar gedung gereja GSKI Perdatam.

Pemeliharaan dan perawatan gedung gereja GSKI Perdatam perlu dilakukan secara berkala, utamanya masalah perbaikan harus dilakukan per 5 tahun. Sementara itu, perbaikan yang dilakukan juga sebaiknya menggunakan material yang berkualitas, demikian juga halnya dalam pelaksanaan perbaikan tersebut. Dalam hal ini, perkiraan besar kerusakan komponen yang berada di atas muka tanah dapat mencapai 25 - 30 persen.

\section{UCAPAN TERIMA KASIH}

Penulis mengucapkan terima kasih disampaikan kepada Lembaga Penelitian dan Pengabdian Masyarakat Uiversitas Kristen Indonesia (LPPM UKI) yang telah memberikan dana untuk terwujudnya pengabdian masyarakat ini. Selain itu, penulis juga mengucapkan terima kasih kepada seluruh pengurus GSKI Perdatam yang telah menyetujui dilaksanakan pengabdian masyarakat ini. 


\section{REFERENSI}

J. Douglas and B. Ransom. (2013). Understanding Building Failures. New York: Routledge.

Rilatupa, J., Siahaan, U., \& Sudarwani, M. M. (2020). Pengembangan Daerah Pariwisata Melalui Pemanfaatan Upacara Adat Rambu Solo Kabupaten Toraja Utara. Jurnal Comunita Servizio, 2(1), 330-338.

Juwana, J. S. (2005). Panduan Sistem Bangunan Tinggi. Jakarta: Erlangga.

Nuswantoro, W. (Juni 2010). Analisis Jenis Kerusakan pada Bangunan Perumahan. Jurnal Rekayasa Rancang Bangun, Vol. 11 No. 1, 1-14.

Hutabarat, L. E., Simanjuntak, P., \& Tampubolon, S. (2019). Peningkatan Kesadaran Masyarakat terhadap Kerusakan Bangunan dan Lingkungan Pasca Gempa, Tsunami dan Likuifaksi di Palu Sulawesi Tengah. JURNAL ComunitÃ Servizio: Jurnal Terkait Kegiatan Pengabdian kepada Masyarakat, terkhusus bidang Teknologi, Kewirausahaan dan Sosial Kemasyarakatan, 1(2), 208-222.

Randall, M. (2012). Environmental Science in Building. New York: Palgrave.

Ratay, R. (2000). Forensic Structural Engineering Handbook. New York: McGraw Hill.

Rostiyanti, S. (2005). Studi Pengaruh Umur Gedung pada Kualitas Pemeliharaan
Sistem Pencegahan Kebakaran. Memperingati 25 Tahun Pendidikan MRK di Indonesia. Bandung: Institut Teknologi Bandung.

Juniasti, R., Sintha, L., M Allo, Y. R., \& Siregar, E. (2020). Improving Community Literation on Bank Perkreditan Rakyat and Bank Pembiayaan Rakyat Syariah (BPR/BPRS). International Journal Of Science and Research, 9(7).

Schmid, K. F. (2014). Building Inspection Manual: $A$ Guide for Building Professionals for Maintenance, Safety, and Assessment. New York: Momentum Press.

Stanford, H. W. (2010). Effective Building Maintenance: Protection of Capital Assets. London: The Fairmont Press, Inc.

Umum, D. P. (2007). Peraturan Menteri Pekerjaan Umum Nomor 45/PRT/M/2007. Jakarta: Departemen Pekerjaan Umum.

Umum, D. P. (2002). Undang-Undang Republik Indonesia No. 28/2002. Bandung: Citra Umbara.

Watt, D. S. (2007). Building Pathology: Principles and Practices. Oxford: Blackwell Sciences Ltd.

Wood, B. (2009). Building Maintenance. Oxford: Blackwell Publishing Ltd.

Wordsworth, P. (2001). Lee's Building Maintenance Management. Oxford: Blackwell Science 